\title{
Hydroelectrolytic Balance and Cerebral Relaxation with Hypertonic Isoncotic Saline versus Mannitol (20\%) During Elective Neuroanesthesia
}

\author{
Walkíria Wingester Vilas Boas, TSA ${ }^{1}$, Mirna Bastos Marques ${ }^{2}$, Atos Alves ${ }^{3}$
} Summary: Vilas Boas WW, Marques MB, Alves A - Hydroelectrolytic Balance and Cerebral Relaxation with Hypertonic Isoncotic Saline versus
Mannitol (20\%) During Elective Neuroanesthesia.

Background and objectives: Cerebral relaxation during intracranial surgery is necessary, and hiperosmolar therapy is one of the measures used to this end. Frequently, neurosurgical patients have sodium imbalances. The objective of the present study was to quantify and determine cerebral relaxation and duration of hydroelectrolytic changes secondary to the use of mannitol versus hypertonic isoncotic solution (HIS) during neurosurgery.

Methods: Cerebral relaxation and hydroelectrolytic changes were evaluated in 29 adult patients before de beginning of infusion, and 30 and 120 minutes after the infusion of equiosmolar loads of approximately $20 \%$ mannitol ( $250 \mathrm{~mL}$ ) or HIS (120 mL). The volume of intravenous fluids infused and diuresis were recorded. A $p<0.05$ was considered significant.

Results: A statistically significant difference in cerebral relaxation between both groups was not observed. Although several changes in electrolyte levels and acid-base balance with mannitol or HIS reached statistical significance only the reduction in plasma sodium 30 minutes after infusion of mannitol, mean of $6.42 \pm 0.40 \mathrm{mEq} \cdot \mathrm{L}^{-1}$, and the increase in chloride, mean of $5.41 \pm 0.96 \mathrm{mEq} . \mathrm{L}^{-1}$ and $5.45 \pm 1.45 \mathrm{mEq} . \mathrm{L}^{-1} 30$ and 120 minutes after infusion of HIS, caused a transitory dislocation of serum ion levels from normal range. The mannitol (20\%) group had a significantly greater diuresis at both times studied compared with HIS group.

Conclusions: A single dose of hypertonic isoncotic saline solution [7.2\% NaCl/6\% HES (200/0.5)] and mannitol (20\%) with equivalent osmolar loads were effective and safe in producing cerebral relaxation during elective neurosurgical procedures under general anesthesia.

Keywords: Saline Solution, Hypertonic; Mannitol; Water-Electrolyte Imbalance; Neurosurgery.

[Rev Bras Anestesiol 2011;61(4): 456-468] @Elsevier Editora Ltda.

\section{INTRODUCTION}

Cerebral relaxation is essential in anesthesia for intracranial surgery, mandatory in cases of intracranial hypertension, and of great interest for other neurosurgical approaches. It has been considered a neuroprotective measure as it can reduce surgical compression, local hypoperfusion, and cerebral ischemia ${ }^{1}$. After opening of the dura-mater intracranial pressure (ICP) is virtually zero but a non-relaxed brain can reduce the working conditions of neurosurgeons ${ }^{2}$. Administration of osmotherapy at the onset of craniotomy before opening the

\footnotetext{
Received from the Hospital Lifecenter, Belo Horizonte, MG, Brazil.

1. Professor, Physician; Coordinator of the Serviço de Anestesiologia of Hospital Municipal Odilon Behrens; Responsible for the CET-HC-UFMG, Anesthesiologist of Hospital Lifecenter$\mathrm{BH}$

2. Anesthesiologist of Hospital Lifecenter-BH

3. Neurosurgeon; Chief of the Serviço de Neurocirurgia of Hospital Lifecenter-BH; Chief of the Serviço de Neurocirurgia of Santa Casa de Misericórdia de Minas Gerais

Submitted on August 1, 2010

Approved on January 4, 2011.

Corresponce to:

Dra. Walkíria Wingester Vilas Boas

Rua São Romão, 343/701

Santo Antônio

30330120 - Belo Horizonte, MG, Brazil

E-mail: walkiria589@hotmail.com
}

dura-mater is one of the interventions used to produce cerebral relaxation in elective neurosurgeries. Osmolality is the primary determinant of water movements through the intact blood-brain barrier (BBB), and it is predictable. If we increase serum osmolality, normal brain tissue would dehydrate, and the cerebral volume, as well as the intracranial pressure, would be reduced ${ }^{3}$. On the other hand, hyperosmotic therapy produces hydroelectrolytic changes that may be a confounding factor in the management of neurosurgical patients who frequently have water and sodium imbalances usually attributed to cerebral salt wasting syndrome, inappropriate antidiuretic hormone secretion, and diabetes insipidus ${ }^{4}$. Mannitol has become the traditional basis of hyperosmolar therapy ${ }^{5}$. However, it can be associated with severe adverse effects such as intravascular volume depletion, rebound ICP elevation, and renal failure ${ }^{6}$. Although it also has potential side effects, hypertonic saline solutions (HS) have gained renewed interest as an alternate therapy and recently have been use in neurosurgical patients ${ }^{7}$. Several clinical studies comparing the effects of mannitol and HS on intracranial pressure have suggested that HS is as effective as mannitol if not better for treating intracranial hypertension ${ }^{8}$. The objective of the present study was to evaluate cerebral relaxation and changes in hydroelectrolytic balance after the intraoperative administration of HS (7.2\%) in starch (hypertonic isoncotic saline - HIS) 
versus mannitol (20\%) in patients undergoing craniotomy for elective neurosurgical procedures.

\section{MATERIAL AND METHODS}

Cerebral relaxation and hydroelectrolytic balance after intravenous administration of $\mathrm{HIS}$ [ $\mathrm{NaCl}(7.2 \%)$ in $\mathrm{HES} \mathrm{(6 \% )]}$ (Hyper HAES, Fresenius Kabi AG) or mannitol (20\%) were evaluated in 29 adult patients undergoing elective craniotomy and cerebral aneurism clipping, arteriovenous malformations, or cerebral tumors. Both groups mannitol (20\%) and HIS were composed of 17 and 12 patients respectively.

Exclusion criteria were as follows: age $<21$ years, initial sodium < $130 \mathrm{mEq} . \mathrm{L}^{-1}$ or $>150 \mathrm{mEq} . \mathrm{L}^{-1}$, metabolic disorders, treatment with hyperosmotic solution up to 24 hours before surgery, or history of heart or renal failure.

Total intravenous anesthesia with propofol (serum target of 2-4 $\mu . \mathrm{mL}^{-1}$ ) and remifentanil (mean dose $0.15-0.35 \mu . \mathrm{kg}^{-1}$. $\mathrm{min}^{-1}$ ) was the anesthetic technique of choice. All patients were intubated and volume-controlled mechanical ventilation with a mixture of oxygen and room air was initiated. Cisatracurium was the muscle relaxant used. Standard monitoring included electrocardiogram, peripheral oxygen saturation $\left(\mathrm{SpO}_{2}\right)$, central temperature (target 36-37 C), capnography (end-expiratory carbon dioxide $-\mathrm{ETCO}_{2}-$ target of $35-40 \mathrm{mmHg}$ ), invasive blood pressure (mean arterial pressure - MAP - target of $70 \mathrm{mmHg}$ ), and diuresis.

Hypotension was treated with a vasopressor (bolus of $100 \mu \mathrm{g}$ of phenylephrine). If necessary, inhalational anesthesia with sevoflurane, at a minimal alveolar concentration of 0.50.75 , was added to manage hypertension. Normovolemia was maintained by the intravenous administration of $0.9 \%$ saline.

After incision of skin, the parameters evaluated were recorded; they included: hemodynamic variables (heart rate - HR, and MAP), central temperature, and laboratorial data (arterial blood gases, and plasma electrolytes, glucose, and osmolality). Hypertonic isoncotic saline or mannitol (20\%) was infused through a peripheral vein with an infusion pump at a rate of $360 \mathrm{~mL} . \mathrm{h}^{-1}$ or $750 \mathrm{~mL} . \mathrm{h}^{-1}$, respectively, for 20 minutes. The total volume of $120 \mathrm{~mL}$ of HIS has an osmolar load close to $250 \mathrm{~mL}$ of mannitol $(20 \%)^{6}$. The same variables were then evaluated and recorded 30 and 120 minutes after the end of the infusion of hyperosmolar therapy besides the intravenous volume administered and dieresis at the beginning of the hyperosmolar infusion, and 30 and 120 minutes after its termination.

Cerebral relaxation was evaluated by the same surgeon who was blind to the hyperosmolar therapy used after its administration upon opening of the dura-mater, in a four-point scale:
1) Perfect relaxation
2) Satisfactory relaxation
3) Firm brain
4) Swollen brain

The statistical software Graphpad PRISM, version 4.03, was used for statistical analysis. Gaussian distribution of variables was assessed by Shapiro normalcy test. Results were reported as mean \pm standard deviation. ANOVA followed by Bonferroni test was used to compare the intragroup means, while the Student $t$ test was used to compare intergroup means. A p $<0.05$ was considered significant.

\section{RESULTS}

A total of 29 patients were included in the study according to the inclusion and exclusion criteria to receive mannitol $(20 \%)$ or HIS as hyperosmolar therapy aiming at achieving cerebral relaxation during elective neurosurgery.

In the mannitol (20\%) group, 12 patients were schedule for elective craniotomy for cerebral aneurism, one for arteriovenous malformation, and four for cerebral tumor. The demographic data of this group included: age $=44 \pm 3.34$ years, weight $=72 \pm 2.81 \mathrm{~kg}$, gender $M / F=8 / 9$, ASA I/II = 4/13.

In the HIS group, six patients were scheduled for elective craniotomy for cerebral aneurism, one for arteriovenous malformation, and five for cerebral tumor. The demographic data of this group included: age $=49.5 \pm 4.52$, weight $=70.75 \pm 3.81$, gender $M / F=6 / 6$, ASA I/II = 2/10.

Statistically significant differences in demographic data between both groups were not observed.

\section{MANNITOL (20\%) GROUP}

Changes in serum sodium concentration: Serum sodium levels showed a significant reduction 30 minutes after infusion of mannitol (20\%) ( $p<0.001)$, a mean of $6.42 \pm 0.40$ mEq.L $\mathrm{L}^{-1}$. After 120 minutes, serum sodium concentration increased $(p<0.01)$ when compared to its level 30 minutes after infusion, but it did not reach the levels prior to infusion of mannitol $(20 \%)(p<0.001)$ (Table I).

Changes in serum chloride concentration: Serum chloride levels showed a significant reduction 30 minutes after infusion of mannitol $(20 \%)(p<0.01)$, but it returned to baseline levels 120 minutes after infusion $(\mathrm{p}<0.01)$ (Table I).

Changes in serum calcium levels: Serum calcium levels showed a reduction 30 minutes after infusion of mannitol $(20 \%)$ ( $p<0.01) ; 120$ minutes after infusion, serum calcium concentration remained reduced when compared to baseline levels $(p<0.01)$ (Table I).

Changes in serum potassium levels: Serum potassium levels were increased by $0.45 \pm 0.08 \mathrm{mEq} \cdot \mathrm{L}^{-1} 30$ minutes after infusion of mannitol $(20 \%)(p<0.01)$, and 120 minutes after infusion it remained elevated when compared to baseline levels $(p<0.01)$ (Table I).

Changes in hemoglobin: Hemoglobin levels 30 and 120 minutes after infusion of mannitol (20\%) differed from baseline levels $(p<0.01)$, but a difference between them was not observed (Table I). 
Table I - Changes in Hydroelectrolytic and Acid-Base Balance after Mannitol (20\%)

$\begin{array}{lll}\begin{array}{l}\text { Before infusion } \\ \text { of mannitol }\end{array} & \text { after infusion } & 120 \text { minutes } \\ \text { (20\%) } & \text { of mannitol } & \text { of mannitol } \\ \text { (baseline data) } & (20 \%) & (20 \%)\end{array}$

\begin{tabular}{|c|c|c|c|}
\hline $\mathrm{Na}+\mathrm{mEq} \cdot \mathrm{L}^{-1}$ & $138.4 \pm 0.48$ & $132.1 \pm 0.67 \cdot$ & $136.9 \pm 0.67=\Delta$ \\
\hline $\mathrm{Cl}^{-} \mathrm{mEq} \cdot \mathrm{L}^{-1}$ & $109.7 \pm 0.67$ & $105.8 \pm 0.66$ & $110.9 \pm 1.04 \Delta$ \\
\hline $\mathrm{K}^{+} \mathrm{mEq} \cdot \mathrm{L}^{-1}$ & $3.67 \pm 0.07$ & $4.19 \pm 0.15=$ & $3.99 \pm 0.19$ \\
\hline $\mathrm{Ca}^{+2} \mathrm{mmol} . \mathrm{L}^{-1}$ & $1.11 \pm 0.01$ & $1.06 \pm 0.01$ & $1.05 \pm 0.01$ \\
\hline $\mathrm{Hb} \cdot \mathrm{L}^{-1}$ & $12.99 \pm 0.38$ & $12.36 \pm 0.42$ & $12.16 \pm 0.46=$ \\
\hline $\mathrm{HCO}_{3}{ }^{-2} \mathrm{mmol}^{-\mathrm{L}^{-1}}$ & $21.99 \pm 0.58$ & $20.77 \pm 0.32$ & $20.24 \pm 1.04=$ \\
\hline BE mmol. $\mathrm{L}^{-1}$ & $-1.58 \pm 0.6$ & $-2.7 \pm 0.47$ & $-4.74 \pm 0.58=\mathbf{A}$ \\
\hline AG & $9.75 \pm 0.69$ & $9.38 \pm 0.86$ & $9.59 \pm 1.57$ \\
\hline $\mathrm{PaCO}_{2} \mathrm{mmHg}$ & $33.42 \pm 0.95$ & $34.64 \pm 0.81$ & $33.09 \pm 1.05$ \\
\hline
\end{tabular}

- $p<0.01$ when compared to baseline data; $\boldsymbol{\Delta} p<0.01$ when compared to 30 minutes after infusion.

Changes in $\mathrm{BE}$ (base excess), $\mathrm{HCO}_{3}{ }^{2}, \mathrm{AG}$ (anion gap), $\mathrm{PaCO}_{2}$ : Base excess 120 minutes after infusion of mannitol $(20 \%)$ differed from baseline levels $(p<0.001)$ and from the levels 30 minutes after infusion $(p<0.01)$. A difference between the baseline level of $B E$ and that 30 minutes after infusion was not observed. A significant reduction in $\mathrm{HCO}_{3}{ }^{-2}$ was observed only 120 minutes after infusion of mannitol $(20 \%)(p<0.01)$. Mean levels of $A G$, as well as mean levels of $\mathrm{PaCO}_{2}$, did not show a significant difference during the study, (Table I).

Diuresis and intravenous volume administered intraoperatively: Diuresis during the period immediately before the administration of mannitol (20\%) until 30 minutes after administration was $376.5 \pm 62.44 \mathrm{~mL}$, and the intravenous fluid administrated $(250 \mathrm{~mL}$ of $20 \%$ mannitol $+0.9 \%$ saline) in the same period was $516.7 \pm 0.49 \mathrm{~mL}$. Between 30 and 120 minutes after administration of mannitol $(20 \%)$, diuresis was $598.7 \pm 110.2 \mathrm{~mL}$, while the intravenous volume ( $0.9 \%$ saline) administered was $1165 \pm 122 \mathrm{~mL}$. A positive correlation was observed between the volume of diuresis from the infusion of mannitol $(20 \%)$ up to 30 minutes after infusion and the serum sodium concentration 30 minutes $(r=0.74, p=0.0006)$ after administration. The intravenous volume infused between the beginning of the infusion of mannitol $(20 \%)$ and the second data collection, 30 minutes after infusion, did not show a significant correlation with serum sodium, potassium, and chloride concentrations, but it showed a negative correlation with serum calcium levels $(r=-0.65, p=0.005)$ and a positive correlation with hemoglobin variation $(r=-0.58, p=0.02)$. On the other hand, the volume infused between 30 and 120 minutes after infusion of mannitol (20\%) did not show a correlation with any changes in serum ion levels, but it did show a correlation with the volume of diuresis $(r=0.73, p=0.006)$.

Cerebral relaxation according to the four-point scale: 13 patients had a score of 1 (perfectly relaxed brain) and four (23.5\%), a score of 2 (satisfactory relaxed brain).

\section{HYPERTONIC ISONCOTIC SOLUTION GROUP (7.2\% NACL IN 6\% HES)}

Changes in serum sodium levels: Mean baseline sodium levels were $136.4 \pm 0.64 \mathrm{mEq} . \mathrm{L}^{-1}$, with significant changes 30 minutes $\left(140.9 \pm 0.97 \mathrm{mEq} . \mathrm{L}^{-1}, \mathrm{p}<0.01\right)$ and 120 minutes (140.1 $\pm 0.97 \mathrm{mEq} . \mathrm{L}^{-1}, \mathrm{p}<0.01$ ) after infusion of HIS (Table II). Serum sodium levels showed a mean increase of $4.56 \pm 0.69 \mathrm{mEq} . \mathrm{L}^{-1}$ and $3.75 \pm 0.90 \mathrm{mEq} . \mathrm{L}^{-1} 30$ and $120 \mathrm{mi}-$ nutes after infusion respectively.

Changes in serum osmolality. Baseline serum osmolality was $292.3 \pm 3.05 \mathrm{mOsm} \cdot \mathrm{kg}^{-1}$, with significant changes 30 minutes $\left(303.2 \pm 3.2 \mathrm{mOsm} . \mathrm{kg}^{-1}, \mathrm{p}<0.01\right)$ and 120 minutes $\left(305.1 \pm 2.89\right.$ mOsm. $\left.\mathrm{kg}^{-1}, \mathrm{p}<0.01\right)$ after infusion of HIS (Table II). Serum osmolality showed a mean increase of $10.89 \pm 1.62 \mathrm{mOsm} \cdot \mathrm{kg}^{-1}$ and $11.5 \pm 1.88 \mathrm{mOsm} \cdot \mathrm{kg}^{-1} 30$ and 120 minutes after infusion, respectively.

Changes in other serum electrolytes: Mean baseline calcium serum levels were $1.08 \pm 0.02 \mathrm{mmol}^{-\mathrm{L}^{-1}}$, and a significant change in serum levels 30 and 120 minutes after infusion of HIS was not observed (Table II). Mean potassium serum levels were $3.63 \pm 0.11 \mathrm{mEq} . \mathrm{L}^{-1}$, and it showed a significant change 30 minutes $\left(3.80 \pm 0.13 \mathrm{mEq} . \mathrm{L}^{1}, \mathrm{p}<0.01\right)$ and $120 \mathrm{mi}-$ nutes $\left(4.06 \pm 0.14 \mathrm{mEq} . \mathrm{L}^{-1}, \mathrm{p}<0.01\right)$ after infusion (Table II). Between 30 and 120 minutes after infusion of HIS, a significant difference in mean serum potassium concentrations were also observed (Table II). Mean baseline chloride serum levels were $109 \pm 1.4 \mathrm{mEq} . \mathrm{L}^{-1}$, and they showed a significant change 30 minutes $\left(114.4 \pm 1.19 \mathrm{mEq} \cdot \mathrm{L}^{-1}, \mathrm{p}<0.01\right)$ and 120 minutes $\left(113.8 \pm 1.7 \mathrm{mEq} . \mathrm{L}^{-1}, \mathrm{p}<0.01\right)$ after infusion of HIS (Table II).

Changes in hemoglobin concentration: Mean baseline hemoglobin concentration was $12.2 \pm 0.59 \mathrm{~g} \cdot \mathrm{L}^{-1}$, with a significant change 30 minutes $\left(11.36 \pm 0.52 \mathrm{~g} \cdot \mathrm{L}^{-1}, \mathrm{p}<0.01\right)$ and 120 minu-

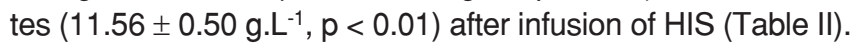

Table II - Changes in Hydroelectrolytic and Acid-Base Balance after Hypertonic Isoncotic Saline Solution

\begin{tabular}{|c|c|c|c|}
\hline & $\begin{array}{l}\text { Before } \\
\text { infusion } \\
\text { (baseline } \\
\text { data) } \\
\end{array}$ & $\begin{array}{l}30 \text { minutes } \\
\text { after infusion }\end{array}$ & $\begin{array}{l}120 \text { minutes } \\
\text { after infusion }\end{array}$ \\
\hline $\begin{array}{l}\text { Osmolality } \\
\text { mOsm.kg-1 }\end{array}$ & $292.3 \pm 3.05$ & $303.2 \pm 3,2$ & $305.1 \pm 2.89$ \\
\hline $\mathrm{Na}+\mathrm{mEq} \cdot \mathrm{L}^{-1}$ & $136.4 \pm 0.64$ & $140.9 \pm 0.90$ & • $140.1 \pm 0.97$ \\
\hline $\mathrm{Cl}-\mathrm{mEq} \cdot \mathrm{L}^{-1}$ & $109 \pm 1.4$ & $114.4 \pm 1.19$ & $113.8 \pm 1.7$ \\
\hline $\mathrm{K}+\mathrm{mEq} \cdot \mathrm{L}^{-1}$ & $3.63 \pm 0.11$ & $3.80 \pm 0.13$ & $4.06 \pm 0.14=\Delta$ \\
\hline $\mathrm{Ca}^{+2} \mathrm{mmol} \cdot \mathrm{L}^{-1}$ & $1.08 \pm 0.02$ & $1.04 \pm 0.02$ & $1.05 \pm 0.02$ \\
\hline $\mathrm{Hb} \cdot \mathrm{L}^{-1}$ & $12.2 \pm 0.59$ & $11.36 \pm 0.52$ & $11.56 \pm 0.50$ \\
\hline $\mathrm{HCO}_{3}{ }^{-2} \mathrm{mmol} \cdot \mathrm{L}^{-1}$ & $22.95 \pm 0.53$ & $21.63 \pm 0.62$ & $20.65 \pm 0.76$ \\
\hline BE mmol. $\mathrm{L}^{-1}$ & $-1.26 \pm 0.67$ & $-2.48 \pm 0.81$ & $-4.22 \pm 0.81=4$ \\
\hline$A G$ & $7.97 \pm 2.1$ & $8.69 \pm 1.78$ & $9.47 \pm 1.83$ \\
\hline $\mathrm{PaCO}_{2} \mathrm{mmHg}$ & $36.68 \pm 1.66$ & $34.49 \pm 1.04$ & $35.09 \pm 1.04$ \\
\hline
\end{tabular}

- $p<0.01$ when compared to baseline data; $\Delta p<0.01$ when compared to 30 minutes after infusion. 
Changes in $\mathrm{BE}$ (base excess), $\mathrm{HCO}_{3}^{-2}$, $\mathrm{AG}$ (anion gap), $\mathrm{PaCO}_{2}$ : Mean baseline BE was $-1.26 \pm 0.67$ mmol.L-1, showing a significant change 30 minutes $\left(-2.48 \pm 0.81 \mathrm{mmol}^{-\mathrm{L}^{-1}}\right.$, $\mathrm{p}<0.01)$ and 120 minutes $\left(-4.22 \pm 0.81 \mathrm{mmol}^{-\mathrm{L}^{-1}}, \mathrm{p}<0.01\right)$ after infusion of HIS (6\%). A statistically significant difference was also observed in BE 30 and 120 minutes after infusion of HIS (Table II). Mean baseline serum $\mathrm{HCO}^{-2}$ was

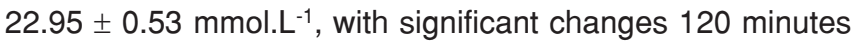
(20.65 $\pm 0.76 \mathrm{mmol}^{\mathrm{L}-1}, \mathrm{p}<0.01$ ) after infusion of HIS (Table II). Mean baseline AG was $7.97 \pm 2.1$ and a statistically significant difference 30 and 120 minutes after infusion of HIS was not observed (Table II). $\mathrm{PaCO}_{2}$ did not show a significant change during the study (Table II).

Diuresis and intraoperative intravenous volume administration: Diuresis during the period immediately before HIS administration and 30 minutes after administration was $127.5 \pm 26.94 \mathrm{~mL}$, while the intravenous volume administered $(120 \mathrm{~mL}$ of HIS $+0.9 \%$ saline) in the same period was $504.2 \pm 109.8 \mathrm{~mL}$. Between 30 and 120 minutes after the administration of HIS the diuresis was $302.7 \pm 83.06 \mathrm{~mL}$, while the intravenous volume administered $(0.9 \%$ saline) was $1323 \pm 192.4 \mathrm{~mL}$. A negative correlation $(r=-0.70, p<0.01)$ was observed between the intravenous volume administered 30 and 120 minutes and $B E 120$ minutes after infusion of HIS.

Cerebral relaxation according to the four-point scale: 10 (83.4\%) patients had a score $=1$ (perfectly relaxed brain), while two patients $(16.6 \%)$ received a score $=2$ (satisfactorily relaxed brain).

\section{MANNITOL (20\%) GROUP VERSUS HS (7.2\%) IN HES (6\%) GROUP}

Regarding cerebral relaxation the neurosurgeon did not consider the brain of any patient inadequate, and statistically significant differences between both groups were not observed. Thirty minutes after hyperosmolar therapy a significant difference was observed in the direction of serum sodium and chloride changes between the mannitol $(20 \%)$ and HIS groups (Table III). While a reduction was observed in serum sodium and chloride levels in the mannitol (20\%) group, there was an increase in the HIS group. During that time, although a significant increase in serum potassium levels was observed in both groups, this increase was more significant in the mannitol (20\%) group (Table III). One hundred and twenty minutes after hyperosmolar therapy, the direction in serum sodium changes remained different in both groups (Table III). Serum potassium levels remained elevated 120 minutes after administration of mannitol $(20 \%)$ and HIS, but without a significant difference between both types of hyperosmolar therapy (Table III). The direction in serum chloride change was the same 120 minutes after administration of mannitol $(20 \%)$ and HIS, but the increase was significant only in the latter group (Tables II and III); 30 and 120 minutes after hyperosmolar therapy, $\mathrm{BE}$ and $\mathrm{HCO}^{-2}$ did not show differences between both groups. The intravenous volume administered was not different between both groups, but diuresis was. The mannitol (20\%) group had a significantly greater diuresis in both study times than the HIS group (Table III).

\section{DISCUSSION}

The present study results showed that hyperosmolar therapy with HIS, composed of $7.2 \% \mathrm{NaCl}$ in $6 \% \mathrm{HES}(200 / 0.5)$, and mannitol $(20 \%)$ is effective in producing cerebral relaxation during elective neurosurgical procedures under general intravenous anesthesia. And although statistically significant differences in diuresis and serum electrolyte and acid-base changes are observed in the first two hours after the administration of both types of hyperosmolar therapies, and among them most of these changes are within or very close to normal range, they are apparently not clinically harmful.

The effects of hypertonic saline (HS) in the brain of patients without intracranial hypertension have been investigated in patients undergoing elective craniotomies for several surgical procedures $7,9,10$. Using a cerebral relaxation scale similar to the one we used, Gemma et al. ${ }^{9}$ reported satisfactory cerebral relaxation in all cases when different osmolar loads but similar volume of HS $(7.5 \%)$ or mannitol $(20 \%)$ were administered. On the other hand, Rozet et al. ${ }^{10}$ observed a

Table III - Variation in Hydroelectrolytic Balance after Mannitol (20\%) and versus Hypertonic Isoncotic Saline Solution

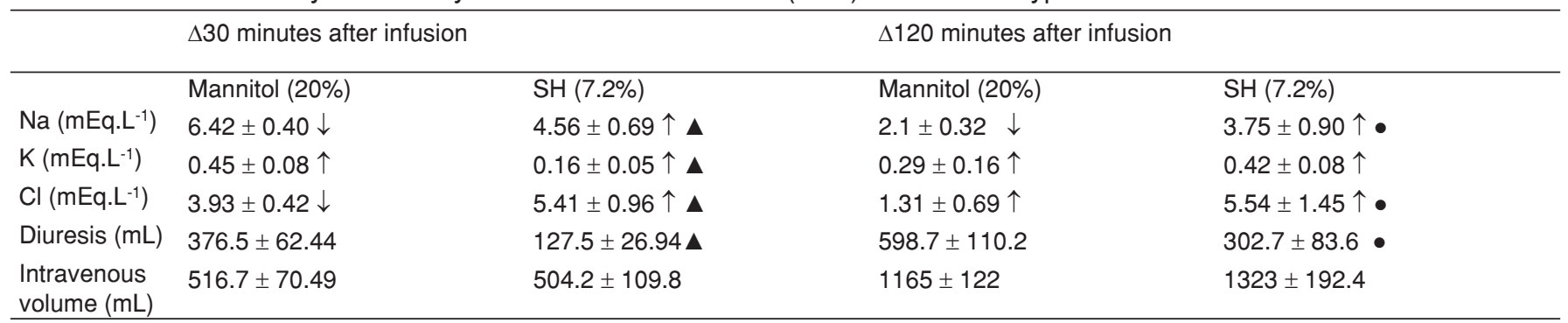

$\uparrow=\Delta$ increase, $\downarrow=\Delta$ reduction when compared to immediately before hyperosmolar therapy. $\Delta p<0.01$ when compared to 30 minutes after mannitol (20\%); $\bullet p<0.05$ when compared to 120 minutes after mannitol (20\%). 
similar effect on cerebral relaxation when equiosmolar solutions of mannitol and HS were used. The main mechanism of action of hyperosmolar solutions is the generation of an osmolar gradient across the blood brain barrier (BBB), due to its impermeability to solutes (sodium and mannitol) ${ }^{10}$, leading to contraction of cerebral tissue (were the BBB is intact) and therefore reducing the ICP. The effectivity of hyperosmolar solutes depends on their reflection coefficient, which determines the relative impermeability of BBB to the solute where 1 (one) means a solute for which the barrier is absolutely impermeable and 0 (zero) means a solute for which it is completely permeable ${ }^{11}$. The reflection coefficient of the membrane for sodium is 1 (different from the reflection coefficient for mannitol, which is 0.9$)^{12}$. In the periphery (muscles, lungs, and other tissues) the reflection coefficient of the endothelial membrane for sodium is only 0.1 meaning that the intracellular, and not interstitial, fluid represents the majority of fluid mobilized after HS administration ${ }^{13}$. Thus, in the periphery water movement from interstitial space to intravascular space is governed by the serum concentration of large molecules (oncotic gradient). In contrast with peripheral capillaries in cerebral capillaries (when the BBB is intact) the endothelial membrane is impermeable to sodium, and water movements across BBB is determined by the total osmotic gradient generated by both large molecules and small ions ${ }^{14}$, while fluid mobilization after the HS administration is from intracellular and interstitial spaces to intravascular space. Since there are very few protein molecules when compared to the number of inorganic ions, its effect on osmolality is minimal (normal POC $\sim 20 \mathrm{mmHg} \sim 1 \mathrm{mosm} \cdot \mathrm{kg}^{-1}$ ) ${ }^{14}$. These differences explain why the administration of large volumes of isotonic crystalloids with dilutional reduction of colloid oncotic pressure (POC) results in peripheral edema, but it does not increase cerebral water content and/or ICP ${ }^{14}$. When serum osmolality increases the osmotic gradient drives water out of brain tissue. In our study a mean increase in serum osmolality of only $10.89 \pm 1.62$ and $11.5 \pm 1.88$ was measure 30 and 120 minutes, respectively, after infusion of HIS. Serum osmolality was always below the safe threshold proposed (320 mOsm. $\left.\mathrm{kg}^{-1}\right)$ during the use of $\mathrm{HS}$ by the Brain Trauma Foundation ${ }^{15}$. Although in our study increases in osmolality with HIS were small, it has been described that even small changes $(<5 \%)$ can modify cerebral water content and ICP ${ }^{16}$. Harutjunyan et al. ${ }^{17}$, using $7.2 \%$ $\mathrm{NaCl} / \mathrm{HES} 200 / 0.5\left(1.4 \mathrm{~mL} . \mathrm{kg}^{-1}\right)$ in the treatment of intracranial hypertension observed an increase in serum osmolality from 284 (272-300) mOsm. $\mathrm{kg}^{-1}$ to 300 (284-319 mOsm. $\mathrm{kg}^{-1}$ ), corresponding to reductions in ICP from 22 (19-31) to $15(8-18) \mathrm{mmHg}$, and increases in cerebral perfusion pressure from $60 \mathrm{mmHg}$ to $72 \mathrm{mmHg}$ in neurosurgical patients. Schwarz et al. ${ }^{18}$, in a study that evaluated $\mathrm{HS}$ and mannitol in patients with elevated ICP after cerebral infarction, demonstrated that the serum osmolarity increased from a baseline level of $310.1 \pm 5.1 \mathrm{mOsm} . \mathrm{L}^{-1}$ to $320.5 \pm 4.6 \mathrm{mOsm} . \mathrm{L}^{-1}$ (after 15 minutes) and to $316.6 \pm 4.8 \mathrm{mOsm}^{-\mathrm{L}^{-1}}$ (after 60 minutes), which correlated with a reduction in ICP. Therefore, although small, the changes in serum osmolality after HS in our study probably contributed to the perfect or satisfactory cerebral re- laxation observed by the neurosurgeon. This study used $7.5 \%$ $\mathrm{NaCl} / 6 \%$ HES (200/0.5) because HS concentrations above $10 \%$ can open tight junctions in BBB ${ }^{13}$. The effect of HS alone is short-acting ${ }^{13}$. With the addition of a colloid, its clinical effect can be prolonged for 2-4 hours ${ }^{13}$. In addition to creating an osmolar gradient across BBB, the reduction in CSF production, improvement in blood rheology, and anti-inflammatory properties of $\mathrm{HS}$ and mannitol seem to have a role in bran therapy $10,18,19$. An impaired BBB has the potential to leak out osmotic substances into the brain parenchyma causing a reverse osmotic effect ${ }^{13}$. The combination of HS and colloid could increase concerns about its safe use. However, in elective neurosurgeries BBB would be intact in most part of the brain. Austrian physicians have extensive experience with the use of a large number of solutions composed of $7.2 \%$ to $7.5 \%$ $\mathrm{NaCl}$ with dextran or $6 \%$ to $10 \% \mathrm{HES}$ and for almost a decade their routine with these solutions indicate a low potential for complications ${ }^{20}$. In theory the most serious obstacle in the treatment with HS would be the development of neurologic complications secondary to osmotic demyelination syndrome (ODS) or central pontine myelinolysis (CPM). The literature on correction of hyponatremia in prospective animal studies and case reports in humans recommend that serum sodium should not be increased above 10-20 mEq.day ${ }^{-1}{ }^{21}$. In our study, we observed a mean increase in serum sodium levels of $4.56 \pm 0.69,30$ minutes, and $3.75 \pm 0.90,120$ minutes after administration of HIS (Table III). Besides, other human triages with HS have not observed very elevated and fast increases in serum sodium nor ODS ${ }^{19}$. Patients have tolerated an acute increase in serum sodium levels up to $155-160 \mathrm{mEq} \cdot \mathrm{L}^{-1}$, apparently without any harm ${ }^{9,14}$. There is still the hypothetic risk that acute brain dehydration could cause mechanical stretching of ligating blood vessels with the consequent subarachnoid hemorrhage ${ }^{13}$. Hypertonic isoncotic saline and $0.9 \%$ saline infused during our study are hyperchloremic ${ }^{22}$, which can increase serum chloride above normal levels such as observed in our study. $\mathrm{HCO}_{3}{ }^{-2}$ and $\mathrm{BE}$ were reduced 30 and 120 minutes after infusion of HIS, which has been observed in other studies ${ }^{23}$, and in all of these most likely as a consequence of the dilutional effects of hyperchloremic acidosis. Hypertonic saline has a tendency to reduce the difference in strong ions leading to metabolic acidosis with normal AG (anion gap) ${ }^{3}$. One hundred and twenty minutes after infusion of HIS a negative correlation $(r=-0.70, p<0.01)$ was observed between $B E$ and the volume infused between 30 and 120 minutes; most likely, the large amount of $0.9 \% \mathrm{NaCl}$ infused in this period produced dilutional effects or hyperchloremic acidosis without significant changes in AG. The impact that hyperchloremic acidosis could have on prognosis remains controversial and may produce diagnostic confusion ${ }^{24}$. Changes in hemoglobin levels with HIS reached statistical significance, but which was not clinically significant, and they probably were a consequence of HIS- and $0.9 \% \mathrm{NaCl}$-induced dilution. Considerable blood loss was not observed in any of the study groups.

Apparently, the hydroelectrolytic changes except for changes in serum potassium levels observed with mannitol during 
neurosurgeries are directly related to intravascular content dilution. Among these changes we should mention transient dilutional hyponatremia which oftentimes can reach levels below the lower limit of normalcy was also reported in other studies ${ }^{10}$. The correlation between hyponatremia and increased diuresis should not be forgotten in the period shortly after infusion of mannitol (20\%), therefore avoiding diagnostic and therapeutic confusion. The diuretic effects of mannitol tend to normalize sodium serum levels, initially reduced, which would be demonstrated by the presence of a positive correlation $(r=0.74$, $p<0.01$ ) between serum sodium levels 30 minutes after mannitol administration and diuresis in that period. Sodium serum levels before 30 minutes after mannitol administration would, most likely, be even lower. Rozet et al. ${ }^{10}$ demonstrated lower sodium serum levels 15 and 30 minutes after mannitol administration. Changes in serum levels of chloride, calcium, and hemoglobin after mannitol administration are most likely dilutional with longer lasting calcium and hemoglobin changes since solutions containing calcium of red blood cells were not administered. The development of hypokalemia with administration of HIS and mannitol has been reported 10,13,19,23,25, most likely as a result of dilutional effects or urinary losses, but the exact mechanism is unknown. Our results revealed increased serum potassium levels, which was statistically significant, but without clinical significance both with mannitol and HIS. And the suggested mechanisms include outflow of cellular potassium with water as a result of hyperosmolar conditions; dilutional acidosis due to expansion of intracellular fluid and dilution of bicarbona- te; or reduction in the difference of strong ions ${ }^{25}$. In general, electrolytic changes associated with the use of mannitol (20\%) were short-lived, since 120 minutes after its infusion serum ions were within normal limits close to pre-infusion levels, although still statistically different. Even the hyponatremia observed 30 minutes after mannitol (20\%) infusion was not present 120 minutes later. Regarding the duration of electrolytic changes associated with HIS, 120 minutes after infusion hyperchloremia still persisted most likely related not only to the amount of chloride in HIS, but also the saline solution used in maintenance infusion and volemic replacement. Hypertonic saline and mannitol have similar neurologic effects, but the fact that HS does not produce an immediate diuretic effect, as observed in our study, simplifies the intraoperative management of fluids ${ }^{14}$, although for Huang et al. ${ }^{23}, \mathrm{HS}$ is a diuretic ${ }^{2}$.

A single dose of hypertonic isoncotic saline $[7.2 \% \mathrm{NaCl} / 6 \%$ HES (200/0.5)] and mannitol (20\%) with equivalent osmolar loads were proven to be effective and safe in producing cerebral relaxation during elective neurosurgical procedures under general anesthesia. Although several differences in electrolytes and acid-base balance reached statistical significance with the use of mannitol or HIS, only the reduction in serum sodium levels, mean of $6.42 \pm 0.40$ mEq. $\mathrm{L}^{-1} 30$ minutes after the infusion of mannitol, and an increase in chloride serum levels, mean $5.41 \pm 0.96 \mathrm{mEq} . \mathrm{L}^{-1}$ and $5.45 \pm 1.45 \mathrm{mEq} . \mathrm{L}^{-1} 30$ minutes and 120 minutes, respectively, after the infusion of HIS, caused a transient dislocation of ion serum levels outside normal limits, Intraoperative diuresis was higher after mannitol than HIS. 


\section{REFERÊNCIAS / REFERENCES}

01. Hans $\mathrm{P}$, Bonhomme $\mathrm{V}$ - Why we still use intravenous drugs as the basic regimen for neurosurgical anaesthesia. Curr Opin Anaesthesiol, 2006;19:498-503.

02. Randell $T$, Niskanen $M$ - Management of physiological variables in neuroanaesthesia: maintaining homeostasis during intracranial surgery. Curr Opin Anaesthesiol, 2006;19:492-497.

03. Tommasino C, Picozzi V - Volume and electrolyte management. Best Pract Res Clin Anaesthesiol, 2007;21:497-516.

04. Tisdall $M$, Crocker $M$, Watkiss J et al. - Disturbances of sodium in critically ill adult neurologic patients: a clinical review. J Neurosurg Anesthesiol, 2006; 18:57-63.

05. Kofke WA, Stiefel M - Monitoring and intraoperative management of elevated intracranial pressure and decompressive craniectomy. Anesthesiol Clin, 2007;25:579-603.

06. Himmelseher $\mathrm{S}$ - Hypertonic saline solutions for treatment of intracranial hypertension. Curr Opin Anaesthesiol, 2007;20:414-426.

07. De Vivo P, Del Gaudio A, Ciritella P et al. - Hypertonic saline solution: a safe alternative to mannitol $18 \%$ in neurosurgery. Minerva Anestesiol, 2001;67:603-611. 
08. Bentsen G, Breivik H, Lundar T et al. - Hypertonic saline (7.2\%) in $6 \%$ hydroxyethyl starch reduces intracranial pressure and improves hemodynamics in a placebo-controlled study involving stable patients with subarachnoid hemorrhage. Crit Care Med, 2006;34:2912-2917.

09. Gemma M, Cozzi S, Tommasino C et al. - 7.5\% hypertonic saline versus $20 \%$ mannitol during elective neurosurgical supratentorial procedures. J Neurosurg Anesthesiol, 1997;9:329-334.

10. Rozet I, Tontisirin N, Muangman S et al. - Effect of equiosmolar solutions of mannitol versus hypertonic saline on intraoperative brain relaxation and electrolyte balance. Anesthesiology, 2007;107:697-704.

11. Tommasino $\mathrm{C}$ - Fluids and the neurosurgical patient. Anesthesiol Clin North America, 2002;20:329-346.

12. Qureshi Al, Suarez Jl - Use of hypertonic saline solutions in treatment of cerebral edema and intracranial hypertension. Crit Care Med, 2000;28:3301-3313.

13. Rocha-e-Silva M, Poli de Figueiredo LF - Small volume hypertonic resuscitation of circulatory shock. Clinics (Sao Paulo), 2005;60:159172.

14. Strandvik GF - Hypertonic saline in critical care: a review of the literature and guidelines for use in hypotensive states and raised intracranial pressure. Anaesthesia, 2009;64):990-1003.

15. The Brain Trauma Foundation. The American Association of Neurological Surgeons. The Joint Section on Neurotrauma and Critical Care. Guidelines for cerebral perfusion pressure. J Neurotrauma, 2000;17:507-511.

16. Tommasino C, Moore S, Todd MM - Cerebral effects of isovolemic hemodilution with crystalloid or colloid solutions. Crit Care Med, 1988;16:862-868.

17. Harutjunyan L, Holz C, Rieger A et al. - Efficiency of $7.2 \%$ hypertonic saline hydroxyethyl starch $200 / 0,5$ versus mannitol $15 \%$ in the treatment of increased intracranial pressure in neurosurgical patients - a randomized clinical trial [ISRCTN62699180]. Crit Care, 2005;9:R530R540.

18. Schwarz S, Schwab S, Bertram M et al. - Effects of hypertonic saline hydroxyethyl starch solution and mannitol in patients with increased intracranial pressure after stroke. Stroke, 1998;29:1550-1555.

19. Tyagi $R$, Donaldson $K$, Loftus $C M$ et al. - Hypertonic saline: a clinical review. Neurosurg Rev, 2007;30:277-289.

20. Schimetta W, Schochl H, Kroll W et al. - Safety of hyperoncotic solutions: a survey from Austria. Wien Klin Wochenschr, 2002;114:89-95.

21. Sterns RH, Riggs JE, Schochet SS Jr - Osmotic demyelination syndrome following correction of hyponatremia. N Engl J Med, 1986, 314:1535-1542.

22. Morris CG, Low J - Metabolic acidosis in the critically ill: part 1. Classification and pathophysiology. Anaesthesia, 2008;63:294-301.

23. Huang SJ, Chang L, Han YY et al. - Efficacy and safety of hypertonic saline solutions in the treatment of severe head injury. Surg Neurol, 2006;65:539-546.

24. Morris CG, Low J - Metabolic acidosis in the critically ill: part 2. Causes and treatment. Anaesthesia, 2008;63:396-411.
25. Flynn BC - Hyperkalemic cardiac arrest with hypertonic mannitol infusion: the strong ion difference revisited. Anesth Analg, 2007;104:225-226.

Resumen: Vilas Boas WW, Marques MB, Alves A - Equilibrio Hidroelectrolítico y Relajación Cerebral con Salino Isoncótico-Hipertónico versus Manitol (20\%) durante Neuroanestesia Electiva.

Justificativa y objetivos: La relajación cerebral es necesaria durante la cirugía intracraneana, y la terapia hiperosmolar es una de las medidas para su producción. Los pacientes neuroquirúrgicos a menudo presentan disturbios del sodio. El objetivo del trabajo fue cuantificar y determinar la relajación cerebral y la duración de las alteraciones hidroelectrolíticas provenientes del uso del manitol versus solución isoncótica hipertónica $(\mathrm{SIH})$, durante la neurocirugía.

Método: Se evaluaron la relajación cerebral y las alteraciones hidroelectrolíticas de 29 pacientes adultos antes, 30 y 120 min después del término de la infusión de carga aproximadamente equiosmolar de manitol 20\% (250 mL) o SIH $(120 \mathrm{~mL})$. Se registró el volumen de los líquidos intravenosos infundidos y la diuresis. El $P<0,05$ fue considerado significativo

Resultados: No hubo ninguna diferencia estadística significativa entre los dos grupos en cuanto a la relajación cerebral. Aunque varias diferencias en los electrólitos y el equilibrio ácido-básico con el uso de manitol o $\mathrm{SIH}$, hayan alcanzado una significancia estadística, solamente la reducción del sodio plasmático $30 \mathrm{~min}$ después del uso del manitol, como promedio de 6,42 $\pm 0,40 \mathrm{mEq} \cdot \mathrm{L}^{-1}$, y la elevación del cloro como promedio $5,41 \pm 0,96 \mathrm{mEq} \cdot \mathrm{L}^{-1}$ y $5,45 \pm 1,45 \mathrm{mEq} \cdot \mathrm{L}^{-1}$, 30 y $120 \mathrm{~min}$ respectivamente después de la $\mathrm{SIH}$, alteraron transitoriamente los niveles séricos de esos iones del rango de la normalidad laboratorial. El grupo del manitol (20\%) tuvo una diuresis significativamente mayor en los dos tiempos estudiados en comparación con el grupo de la $\mathrm{SIH}$.

Conclusiones: La solución salina isoncótica-hipertónica [ $\mathrm{NaCl} 7,2 \% /$ HES $(200 / 0,5) 6 \%$ y manitol $(20 \%)$, en dosis única con carga osmolar equivalente, fueron efectivos y seguros para generar la relajación cerebral durante los procedimientos neuroquirúrgicos electivos bajo la anestesia general.

Descriptores: CIRUGÍA: Neurocirugía; FÁRMACOS: Manitol, Solución hipertónica; METABOLISMO. 